\author{
Sustinere \\ Journal of Environment and Sustainability \\ Volume 1 Issue 1 (2017) $48-62$ \\ Print ISSN: 2549-1245 Online ISSN: 2549-1253 \\ Website: https://sustinerejes.com E-mail: sustinere.jes@iain-surakarta.ac.id
}

\title{
RESEARCH PAPER \\ Design of the wastewater treatment system of an office building
}

\author{
Rizky Raissha Yasmine*, Mas Agus Mardyanto \\ Department of Environmental Engineering, Sepuluh Nopember Institute of Technology Surabaya, \\ Indonesia \\ Article history: \\ Received 4 July 2017 | Accepted 8 August 2017 | Available online 11 September 2017
}

\begin{abstract}
The MIPA Tower office building, an eleven-storey building, which is located in the area of Institut Teknologi Sepuluh Nopember Surabaya, is under construction. The building will be utilized for offices, classrooms, and laboratories. In the operation of the building, domestic and laboratory wastewater will be produced. This wastewater contains compounds that can pollute the environment. A domestic and laboratory wastewater treatment system is designed. The system comprises of a neutralization tank, a grease trap, an equalization tank, an anaerobic filter, and an activated carbon and silica sand filter. The steps of the design are (i) collecting primary data and secondary data, (ii) calculating the engineering design, (iii) drawing the Detailed Engineering Design (DED), and (iv) calculating the bill of quantity and budget. The conclusion of this design is that the treatment plant will treat a mixture of domestic and laboratory wastewater. The dimension of each unit is as follows: (i) the neutralization $\operatorname{tank}(\varnothing=0.65 \mathrm{~m}, \mathrm{H}=0.43 \mathrm{~m})$, (ii) the grease trap $(4 \mathrm{~m} \times 2 \mathrm{~m} \times 1 \mathrm{~m})$, (iii) the equalization tank (10.5 m x $5.5 \mathrm{~m} \times 2.5 \mathrm{~m}$ ), (iv) the septic tank ( $4.5 \mathrm{~m} \mathrm{x} 4 \mathrm{~m} \times 2.5 \mathrm{~m}$ ), (v) the six-compartment anaerobic filter $(2.25 \mathrm{~m} \mathrm{x} 4 \mathrm{~m} \mathrm{x} 2.5 \mathrm{~m})$, and (vi) the filter with activated carbon $(\mathrm{H}=50 \mathrm{~cm})$, silica sand $(\mathrm{H}=150 \mathrm{~cm})$, and gravel $(\mathrm{H}=10 \mathrm{~cm})$, with the diameter of the tank is $1.5 \mathrm{~m}$.
\end{abstract}

Keywords: anaerobic filter; domestic; laboratory; office building; wastewater

\section{Introduction}

Vertical development is a development of multi-storey building with various functions, from housing to commercial interests, such as offices, that will produce wastewater in the form of greywater and blackwater. The Matematika dan IPA (MIPA) Tower office building, which is located in the area of Institut Teknologi Sepuluh Nopember (ITS) Surabaya, Indonesia, was under construction. It is an eleven-storey building that will be utilized for offices, classrooms and laboratories, and will produce both domestic and laboratory wastewater. However, in the time of the study, the MIPA Tower office building was not equipped with a wastewater treatment plant.

\footnotetext{
${ }^{{ }^{*} 1}$ correspondent author. E-mail: rraissha16@gmail.com DOI 10.22515/sustinere.jes.v1i2.15
} 
In Indonesia, untreated domestic wastewater from housing activities, such as bathing and laundry, is still commonly discharged into drainage channels which were originally designed for surface runoff. Even solid waste and wastewater are very often disposed of into the water body (river). As a result, based on the monitoring of the Ministry of Environment of the Republic of Indonesia in 2014, as much as 75\% of streams in Indonesia has been heavily polluted by household wastewater discharges, including Cisadane River in Tangerang City. The reason why residents prefer to throw garbage into the river is that it is considered more practical and free. Additionally, how it has become a habit and the lack of facilities leads to a worse environmental problem (Penny, et al, 2012). This condition results in the growth and spreading of an epidemic or endemic water-born diseases (Sasongko, 2006). Surabaya, the second biggest city in Indonesia, does not have a centralized wastewater treatment plant. Hence, a decentralized wastewater treatment plant is still the best option to solve the wastewater treatment problem.

Beside domestic wastewater, there was also laboratory wastewater produced from the MIPA Tower. Laboratory wastewater is very complex and it consists of chemical waste and water from sinks used for washing and cleaning of equipment from laboratory practices that contains organic and inorganic, acids, bases, irritating, reactive and toxic compounds as well as heavy metals (Hartini, et al, 2011).

Based on the problems explained, an action is needed, and one of them is through a wastewater treatment system design with an anaerobic filter unit and a pretreatment. An anaerobic filter is a suitable unit for all industrial wastewater with low suspended solid (Sasse, 1998). While a pretreatment is intended for laboratory wastewater for its complex composition and its possibility of containing toxic materials that are dangerous for the microorganism in biological wastewater treatment (Tchobanoglous, 2014).

This study focused on the design of wastewater treatment system using neutralization tank, grease trap, equalization tank, septic tank, anaerobic filter, and filter for both domestic and laboratory wastewater of the MIPA Tower office building. This study was conducted to meet the quality standards of effluent as listed in East Java Governor Regulation No.72 of 2013 (Peraturan Gubernur Jawa Timur No.72 Tahun 2013) regarding the Quality Standard of Wastewater for Laboratory and Clinic before discharging to water bodies.

\section{Study of literature}

\subsection{Definition}

According to the Government Regulation of the Republic of Indonesia Number 82 of 2001 (Peraturan Pemerintah Republik Indonesia Nomor 82 Tahun 2001), wastewater is the residue of a business and or activity in the form of liquid. Meanwhile, according to Tchobanoglous et al (2003), wastewater is a combination of liquids and garbages (water coming from residential, commercial, offices and industrial areas) together with groundwater, surface water and possibly rainwater.

Domestic wastewater is a liquid waste originating from urban communities including urban waste. Sources of domestic wastewater are all liquid waste derived from household waste which includes: liquid domestic waste that is the disposal of bathroom, kitchen, 
laundry, and others (Yudo and Setiyono, 2008). Domestic wastewater is wastewater from household wastewater including hotels, guesthouses, hospitals, apartments, markets, offices, schools, social facilities and commercial areas (Widayat, 2009). According to the Decree of the Minister of Environment No. 112 of 2003 on the Quality Standard of Domestic Wastewater (Keputusan Menteri Lingkungan Hidup No. 112 Tahun 2003 tentang Baku Mutu Air Limbah Domestik), domestic wastewater is wastewater from business and/or residential activities (real estate), restaurants, offices, commerce, apartments, and dormitories.

\subsection{General Characteristics of Wastewater}

Urban domestic wastewater contains more than $99.9 \%$ water. Other materials are suspended and dissolved organic and inorganic compounds and microorganisms. These materials provide physical, chemical, and biological qualities that are the characteristics of domestic and industrial waste. The physical qualities of urban waste include temperature, color, odor and turbidity (Qasim, 1991). Santoso (2015) stated that the biological characteristics of liquid waste are usually influenced by the content of microorganisms in the liquid waste. While based on chemical character, chemical compound contained in wastewater consists of three groups, namely organic compounds (proteins, carbohydrates, fats), inorganic compounds (nitrogen, phosphate, sulphate), and gas.

Wastewater characteristics that are of concern in the design of the distribution system and the wastewater treatment of ITS Surabaya MIPA Tower Building Building include BOD, COD, TSS, phenol, nitrogen, phosphate, oils and fats, and $\mathrm{pH}$ in accordance with quality standard parameters in Regulation East Java Governor No.72 of 2013 on Quality Standard of Wastewater for Laboratory and Clinic (Peraturan Gubernur Jawa Timur No. 72 Tahun 2013 tentang Baku Mutu Air Limbah Bagi Laboratorium dan Klinik).

Mara (1978) stated that the strength of a community's wastewater is also related to its water consumption. In the USA, where the consumption of clean water is high i.e. 350$400 \mathrm{~L} /$ person.day, has a weak wastewater strength $\left(\mathrm{BOD}_{5}=200-250 \mathrm{mg} / \mathrm{L}\right)$. Whereas in tropical countries, $\mathrm{BOD}_{5}$ concentrations of wastewater reach $400-700 \mathrm{mg} / \mathrm{L}$, or it can be said to be strong, but have a lower water consumption of 40-100 L/person.day (Mara, 1978). In terms of the concentration of $\mathrm{BOD}_{5}$ and COD, the strength of wastewater can be categorized as weak, medium, strong and very strong.

\subsection{Quality of Domestic Wastewater}

The results of Flint's research (1992) in Santoso (2014) reported that the composition of domestic wastewater is fat (33\%), protein $(25 \%)$, cellulose $(8 \%)$, starch (8\%), lignin (6\%), and ash (20\%) with BOD concentration ranging from $275-3000 \mathrm{mg} / \mathrm{L}$. Domestic wastewater generally contains high enough organic pollutant compounds and can be treated by the biological process (Yudo and Setiyono, 2008). Domestic wastewater can also contain pathogenic organisms that can cause disease and nutrients especially $\mathrm{P}$ and $\mathrm{N}$ elements that can cause eutrophication, thus, it must be processed first before discharging into water bodies. 
In developing countries including Indonesia, domestic pollution is the largest amount of pollutants $(85 \%)$ entering water bodies, while in developed countries only constitute $15 \%$ (Sasongko, 2006). The information on the domestic wastewater characteristics is required to determine which method of treatment can be applied.

\subsection{Quality of Laboratory Wastewater}

The chemistry laboratory of a school or institution is one of the producers of liquid, solid and even gas pollutants. Although its quantity and frequency are small, the contents of pollutants are varied and some contain hazardous waste (Widjajanti, 2009). Waste from chemical, biological and/or microbiological experiments involving various natural and synthetic samples, might fall under the hazardous waste category. Heavy metals, high organic compounds, low $\mathrm{pH}$ conditions, and various non-measurable (non-quantitative) hazardous substances are common conditions in the wastewater (Martinez A., et al., 2013). Since this wastewater differs from domestic one, a pretreatment is required to produce an equivalent effluent. The best strategy to clean up toxic and contaminated waste is, in general, cultivate it at the source (Nasr, et al., 2004).

Types of commonly used chemicals in the laboratories include acidic, basic, organic and inorganic chemicals. Types of strong acids used including hydrochloric acid ( $\mathrm{HCl}$ ), nitric acid $\left(\mathrm{HNO}_{3}\right)$, sulfuric acid $\left(\mathrm{H}_{2} \mathrm{SO}_{4}\right)$ and others. Some of the weak acids used including phosphoric acid $\left(\mathrm{H}_{3} \mathrm{PO}_{4}\right)$, carboxylic acids $(\mathrm{HCOOH})$ and so on. While bases that commonly used are sodium hydroxide $(\mathrm{NaOH})$ and potassium hydroxide $(\mathrm{KOH})$. The group of inorganic chemicals includes various types of salts such as sodium chloride ( $\mathrm{NaCl}$ ), magnesium chloride $\left(\mathrm{MgCl}_{2}\right)$, potassium chloride $(\mathrm{KCl})$, mercury sulphate $\left(\mathrm{HgSO}_{4}\right)$, potassium chromate $\left(\mathrm{KCrO}_{4}\right)$, potassium dichromate $\left(\mathrm{K}_{2} \mathrm{CrO}_{7}\right)$, ferro ammonium sulphate $\left(\mathrm{Fe}\left(\mathrm{NH}_{4} \mathrm{SO}_{4}\right)_{2}\right)$ and various other types of salt.

\subsection{Pre-Treatment, Anaerobic System and Filtration}

\subsubsection{Pretreatment}

As mentioned, laboratory waste contains harmful toxic and hazardous compounds when released into the environment. In general, the process of laboratory waste is preceded by a chemical pretreatment and then followed by biological treatment for biodegradable waste. Chemical effluent treatment that is often applied is disinfection, precipitation, colloidal (destabilization) coagulation, oxidation and ion exchange (Rahardjo, 2002). Neutralization can also be used in chemical waste treatment processes to neutralize acidic or alkaline condition.

\subsubsection{Anaerobic System}

Anaerobic decomposition consists of a series of microbiological processes that convert organic matter into methane (Herlambang, 2001). It is commonly used for wastewater treatment with a very high BOD load (Said, 2000). According to Iskandar et al (2016), anaerobic treatment system is the most preferred for community-based 
settlement-scale systems to date. This is due to the operational convenience considerations since it does not require oxygen injection into the processing unit. Individual septic tank and communal domestic wastewater treatment plant use the principle of processing wastewater under anaerobic condition.

Anaerobic condition is a condition where there is no free oxygen. Anaerobic treatment occurs through the breakdown of molecules via a series of fermentation processes by microorganisms. Tchobanoglous et al (2014) stated that the process of fermentation in anaerobic treatment takes place in four stages, namely hydrolysis, acidogenesis, acetogenesis and methanogenesis.

\subsubsection{Filtration}

Basically, filtration is a natural process occurring in the soil, where the groundwater passes through the grained media of the soil, during which a screening process occurs. This natural process is then adapted and engineered in the form of filter units (Masduqi and Assomadi, 2012). The filtration process in wastewater treatment aims to remove suspended and colloidal particles. Particulate filtration is a natural purification through a filtration media for unwanted organic and inorganic contaminants, compounds that cause flavor and odor, color, and pathogens (Putra, 2013).

Filter media is the filter part that plays a role in the filtering process. It can be composed of natural silica sand, anthracite, garnet (Masduqi and Assomadi, 2012) or activated carbon (Puspitahati, 2012) with variations of size and shape. Puspitahati (2012) reported that the effective height ratio between active carbon and sand is 1: 3 in dual media filtration.

\section{Methodology}

\subsection{Data collection}

It is the stage of collecting data required to design the domestic and laboratory wastewater treatment system, which consists of primary and secondary data. The primary data needed in this study is fluctuation of water consumption, domestic wastewater flow rate, and quality of the wastewater. While for the secondary data is laboratory wastewater flowrate, building plan, space usage plan, building facilities and land area available.

\subsection{Data processing and analysis}

Collected data is processed and analyzed for later to be used as the bases for designing the wastewater treatment system. Data processing and analysis performed at this stage are as follows:

- $\quad$ Establishment of the processing scheme

The processing scheme based on units of wastewater treatment system such as neutralization tank, grease trap, equalization tank, septic tank, anaerobic filter and filter, was created to give a picture of treatment system plan and to facilitate designers in designing the processing units as well. 
- $\quad$ Calculation of units of wastewater treatment system

The calculation for each unit follows the guidelines (Tchobanoglous et al, 2014, and Sasse, 1998) with units including neutralization tank, grease trap, equalization tank, septic tank, anaerobic filter and carbon filter.

Calculation of domestic wastewater flowrate

$$
Q_{w}=80 \% x Q_{d}
$$

Where $\quad: Q_{w}=$ domestic wastewater flowrate

$Q_{d}=$ clean water flowrate

The domestic wastewater and laboratory wastewater produced will then be processed together (incorporation of domestic wastewater treatment and laboratory). Merger is done after pretreatment process of laboratory wastewater in neutralization tank. The incorporation of wastewater quality is calculated using the following formula:

$$
[C]_{1,2}=\frac{\left(Q_{1}[C]_{1}\right)+\left(Q_{2}[C]_{2}\right)}{Q_{1}+Q_{2}}
$$

Where $\quad: Q_{1}=$ total flowrate of domestic waste $\left(\mathrm{m}^{3} / \mathrm{s}\right)$

$Q_{2}=$ total flowrate of laboratory waste $\left(\mathrm{m}^{3} / \mathrm{s}\right)$

$C_{1}=$ concentration of domestic waste $(\mathrm{mg} / \mathrm{l})$

$C_{2}=$ concentration of laboratory waste $(\mathrm{mg} / \mathrm{l})$

Calculation of volume of neutralization tank, using the basic formula, to multiply flowrate with given detention time, as follows:

$$
\text { Volume }=Q \times t d
$$

Where $: Q=$ total flowrate of laboratory waste $\left(\mathrm{m}^{3} / \mathrm{s}\right)$

$T d=$ detention time

The following formula is generally used for determining the volume of cylindrical tank or its diameter if the volume and height are known.

$$
\text { Volume }=\frac{1}{4} x \pi x(D)^{2} \times H
$$

Where $: \pi=$ a constant, 3.14

$$
\begin{aligned}
& D=\text { diameter }(\mathrm{m}) \\
& H=\text { height }(\mathrm{m})
\end{aligned}
$$

The volume of a rectangular and square tank is calculated using the basic formula as follows.

$$
\text { Volume }=\text { length } x \text { width } x \text { height }
$$

Calculation of the area of filtration tank using the following formula, when the wastewater flow rate and the designated filtration velocity are known.

$$
\text { Area }=Q / \text { speed of filtration }
$$

Where $\quad: Q=$ total flow rate of wastewater $\left(\mathrm{m}^{3} / \mathrm{s}\right)$ 
The following formula is generally used for determining the area of a circle, or its diameter if the area is known.

$$
\text { Area }=\frac{1}{4} x \pi \times D^{2}
$$

Where $\quad: \pi=$ a constant, 3.14

$D=$ diameter $(\mathrm{m})$

- Design the drawings of units of wastewater treatment system

The drawings of units of wastewater treatment system are made based on the results of the calculation in the previous step.

\section{Result and discussion}

\subsection{Wastewater flowrate}

Total water demand of ITS per 2016 is $387,630 \mathrm{~m}^{3}$, where $15.1 \%$ of the total population are from FMIPA ITS (Facilities and Infrastructure of ITS, 2016). In other word, the water demand of FMIPA ITS is equal to $58,495.2 \mathrm{~m}^{3} /$ year or $4,874.6 \mathrm{~m}^{3} /$ month or $162.5 \mathrm{~m}^{3} /$ day. As much as $10 \%$ of the use of clean water is for laboratory activities and becomes laboratory wastewater. The remaining $90 \%$ is used in domestic activities and becomes domestic wastewater. The amount of clean water that will become domestic wastewater is estimated as much as $70 \%$ to $80 \%$ of the used clean water (Pratiwi and Purwanti, 2015). To calculate the amount of domestic wastewater flowrate, equation (1) is used and it is known that the flow rate of domestic wastewater is $117 \mathrm{~m}^{3} /$ day.

Wastewater from laboratory activities is carried out after waste collection for 1 semester (6 months), so the 6-month discharge is the daily flow rate of laboratory wastewater. The volume of laboratory wastewater collection is $0.85 \mathrm{~m}^{3}$. This amount of wastewater then added with, as mentioned before, as much as $10 \%$ of the use of clean water (162.5 $\mathrm{m}^{3} /$ day) used for laboratory activities and becomes laboratory waste, so the amount of total laboratory wastewater flow rate is $17.1 \mathrm{~m}^{3} /$ day.

Total wastewater flowrate used is obtained from the sum of domestic and laboratory wastewater flow rate, which is equal to $134.1 \mathrm{~m}^{3} /$ day.

\subsection{Quality of domestic wastewater}

The samples was taken in the Environmental Engineering Department because of the existing condition of FMIPA which was not possible to take samples. Samples were taken on Tuesday and Friday, at the same hour using composite sampling technique. Those samples were then analyzed in the Environmental Quality Management Laboratory of Environmental Engineering Department. The results of the analysis can be seen in Table 1.

\subsection{Quality of laboratory wastewater}

Laboratory wastewater samples were taken from waste that has been stored for 1 semester, by composite sampling technique, then tested in the laboratory. Test results are presented in Table 2. 
Table 1. Quality of domestic wastewater

\begin{tabular}{lcccccl}
\hline \multirow{2}{*}{ Parameter } & \multirow{2}{*}{ Unit } & $\begin{array}{c}\text { Standard } \\
\text { Quality }\end{array}$ & I & II & Average & $\begin{array}{c}\text { Analysis } \\
\text { Method }\end{array}$ \\
\hline $\mathrm{pH}$ & - & $6-9$ & 6.35 & 6,65 & 6,5 & pH meter \\
TSS & $\mathrm{mg} / \mathrm{L}$ & $30^{* *}$ & 84 & 186 & 135 & Gravimetry \\
$\mathrm{COD}$ & $\mathrm{mg} / \mathrm{L} \mathrm{O}_{2}$ & $50^{*}$ & 183 & 46 & 114.5 & Reflux/ \\
BOD & $\mathrm{mg} / \mathrm{L} \mathrm{O}_{2}$ & $30^{* *}$ & 112 & 26 & 69 & Tetrimetry \\
Fat and Oil & $\mathrm{mg} / \mathrm{L}$ & $5^{* *}$ & 16 & 4 & 10 & Gravimetry \\
\hline
\end{tabular}

The results of laboratory tests show a fairly high number. This can be due to low wastewater flowrate so that the concentration of wastewater becomes more concentrated and the length of time to store waste effects, as well.

Table 2. Quality of laboratory wastewater

\begin{tabular}{llccl}
\hline \multicolumn{1}{c}{ Parameter } & \multicolumn{1}{c}{ Unit } & Standard Quality & Results & \multicolumn{1}{c}{ Analysis Method } \\
\hline $\mathrm{pH}$ & & $6-9$ & 1.3 & $\mathrm{pH}$ meter \\
$\mathrm{TSS}$ & $\mathrm{mg} / \mathrm{L}$ & 35 & 938 & Gravimetry \\
$\mathrm{COD}$ & $\mathrm{mg} / \mathrm{L} \mathrm{O}_{2}$ & 85 & 29,700 & Reflux/Tetrimetry \\
BOD & $\mathrm{mg} / \mathrm{L} \mathrm{O}_{2}$ & 35 & 10,690 & Winkler \\
Fat and Oil & $\mathrm{mg} / \mathrm{L}$ & 5 & 5,900 & Gravimetry \\
Nitrogen & $\mathrm{mg} / \mathrm{L} \mathrm{NH}_{3}-\mathrm{N}$ & 0.1 & 717.7 & Kjeldahl \\
Phospate & $\mathrm{mg} / \mathrm{L} \mathrm{PO}_{4}-\mathrm{P}$ & 2 & 298.13 & Spectrophotometry \\
Chlor & $\mathrm{mg} / \mathrm{L} \mathrm{Cl}_{2}$ & 0.5 & 0 & Iodimetri \\
Detergent & $\mathrm{mg} / \mathrm{L} \mathrm{LAS}$ & 5 & 158.57 & Spectrophotometry \\
Phenol & $\mathrm{mg} / \mathrm{L}$ & 0.5 & 6.03 & Spectrophotometry \\
Total coliform & $\mathrm{MPN} / 100 \mathrm{~mL}$ & 4000 & 0 & Multi tube fermentation \\
\hline
\end{tabular}

\subsection{Quality of combined wastewater}

Laboratory wastewater after the neutralization process enters the grease trap unit and mixing occurs between the laboratory wastewater with domestic wastewater. The quality of mixed wastewater is calculated based on equation (2) and presented in Table 3.

Table 3. Quality of combined wastewater

\begin{tabular}{lccccc}
\hline \multicolumn{1}{c}{ Parameter } & Unit & $\begin{array}{c}\text { Standard } \\
\text { Quality }\end{array}$ & $\begin{array}{c}\text { Laboratory } \\
\text { Concentration }\end{array}$ & $\begin{array}{c}\text { Domestic } \\
\text { Concentration }\end{array}$ & $\begin{array}{c}\text { Mixed } \\
\text { Concentration }\end{array}$ \\
\hline $\mathrm{pH}$ & - & $6-9$ & 1.3 & 6,5 & - \\
$\mathrm{TSS}$ & $\mathrm{mg} / \mathrm{L}$ & 35 & 77.7 & 135 & 127.7 \\
$\mathrm{COD}$ & $\mathrm{mg} / \mathrm{L} \mathrm{O}_{2}$ & 85 & $1,484.0$ & 114.5 & 289.5 \\
$\mathrm{BOD}$ & $\mathrm{mg} / \mathrm{L} \mathrm{O}_{2}$ & 35 & 538,3 & 69 & 129.0 \\
Fat and Oil & $\mathrm{mg} / \mathrm{L}$ & 5 & 283.5 & 10 & 45.0 \\
Nitrogen & $\mathrm{mg} / \mathrm{L} \mathrm{NH}_{3}-\mathrm{N}$ & 0,1 & 34.0 & 35.52 & 35.3 \\
Phospate & $\mathrm{mg} / \mathrm{L} \mathrm{PO}_{4}-\mathrm{P}$ & 2 & 16.0 & 7 & 8.1 \\
Chlor & $\mathrm{mg} / \mathrm{L} \mathrm{Cl}_{2}$ & 0,5 & 0.5 & 0 & 0.1 \\
Detergent & $\mathrm{mg} / \mathrm{L} \mathrm{LAS}$ & 5 & 12.3 & 0 & 1.6 \\
Phenol & $\mathrm{mg} / \mathrm{L}$ & 0,5 & 0.8 & 0 & 0.1 \\
Total Coliform & $\mathrm{MPN} / 100 \mathrm{~mL}$ & 4000 & 0.0 & 0 & 0.0 \\
\hline
\end{tabular}




\subsection{Wastewater treatment plant design \\ 4.5.1 The neutralization tank design}

The neutralization tank is used for wastewater and acid or base mixing process in order to obtain desired neutral $\mathrm{pH}$. The dimension of neutralization tank is determined with equations (3) and (4).

The diameter of the tank is $0.65 \mathrm{~m}$ and the height of the water is $0.43 \mathrm{~m}$. The base used for neutralization is a $40 \mathrm{~L}$ of $1 \mathrm{M} \mathrm{NaOH}$. The neutralization tank is equipped with an impeller used for mixing between wastewater and base solution. A mixing process occurs between a 6-month stored wastewater and wastewater from washing and cleaning purposes $(10 \%$ of clean water demand).

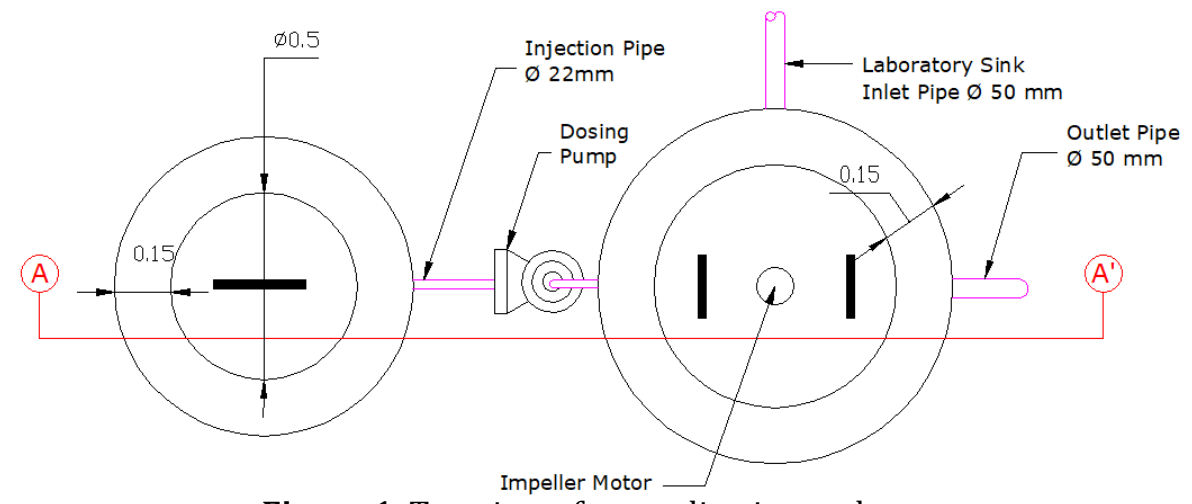

Figure 1. Top view of neutralization tank

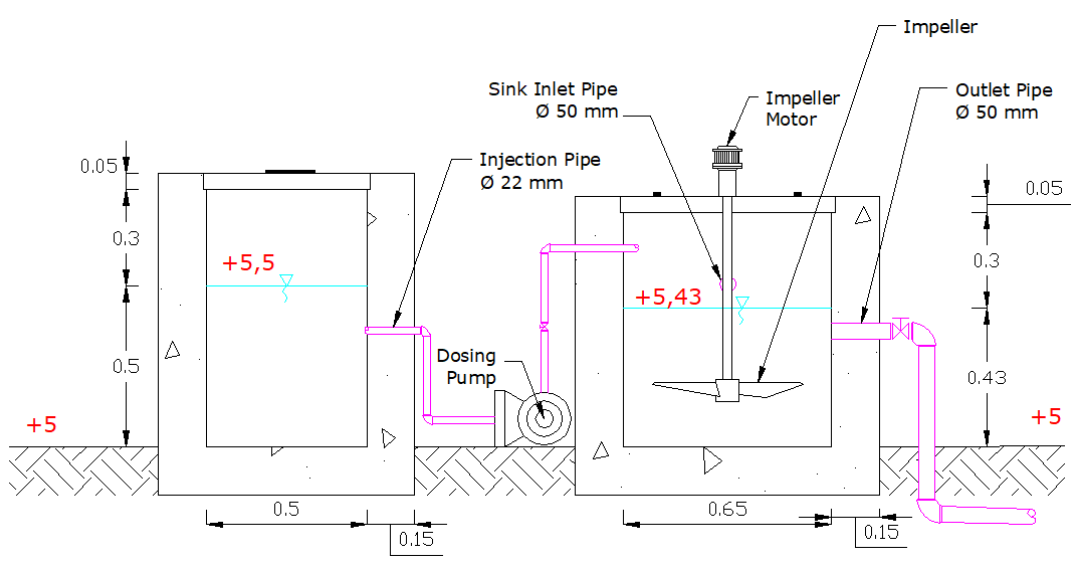

Figure 2. Section A-A' of neutralization tank

\subsubsection{Grease trap design}

The concentration of fat and oil in domestic and laboratory mixed wastewater that have not complied with the quality standard then requires a separation unit, grease trap, before goes into the biological treatment unit. Grease trap can remove fat and oil content up to $80 \%$ (Wongthanate, et al, 2014). Based on the Equation 3, the volume of grease trap required is $5.2 \mathrm{~m}^{3}$. The shape of the designed grease trap is rectangular, so the dimension is obtained using the equation (5) that involves the multiplication of length, width and height. 
The dimension of grease trap is $4 \mathrm{~m} \times 2 \mathrm{~m} \times 1 \mathrm{~m}$, with two compartments for grease floatation area and one extra compartment for the polishing process. A mixing occurs between laboratory and domestic wastewater.

\subsubsection{Equalization tank design}

Equalization tank serves to equalize the flow rate or the quantity of wastewater discharged in order to acquire constant flowrate, which is the average flow rate (5.6 $\mathrm{m}^{3}$ /day). Using Equation (3), with the value of $\mathrm{Q}$ is the combination of domestic and laboratory wastewater flowrate $\left(134.1 \mathrm{~m}^{3} /\right.$ day), and using Equation (5), the dimension of equalization tank designed is $10.5 \mathrm{~m} \times 5.5 \mathrm{~m} \times 2.5 \mathrm{~m}$. To prevent any sedimentation process occurs, a recirculation submersible pump placed inside where twice of the average wastewater flowrate is pumped out. Half of the flow rate will be recirculated into equalization tank, and the rest will be pumped into the septic tank.

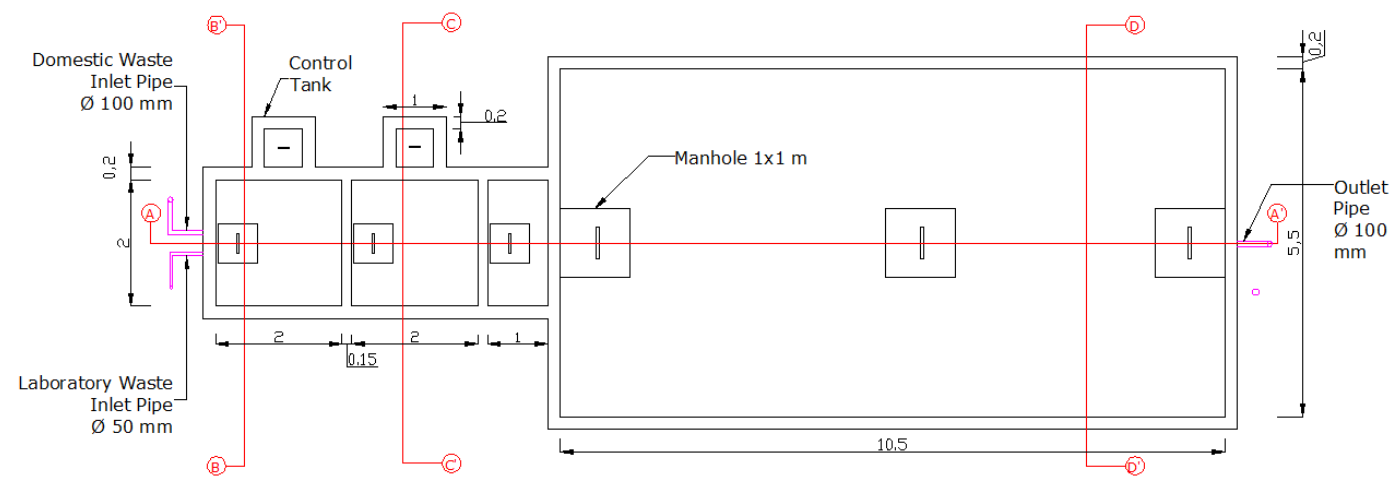

Figure 3. Top view of grease trap and equalization tank

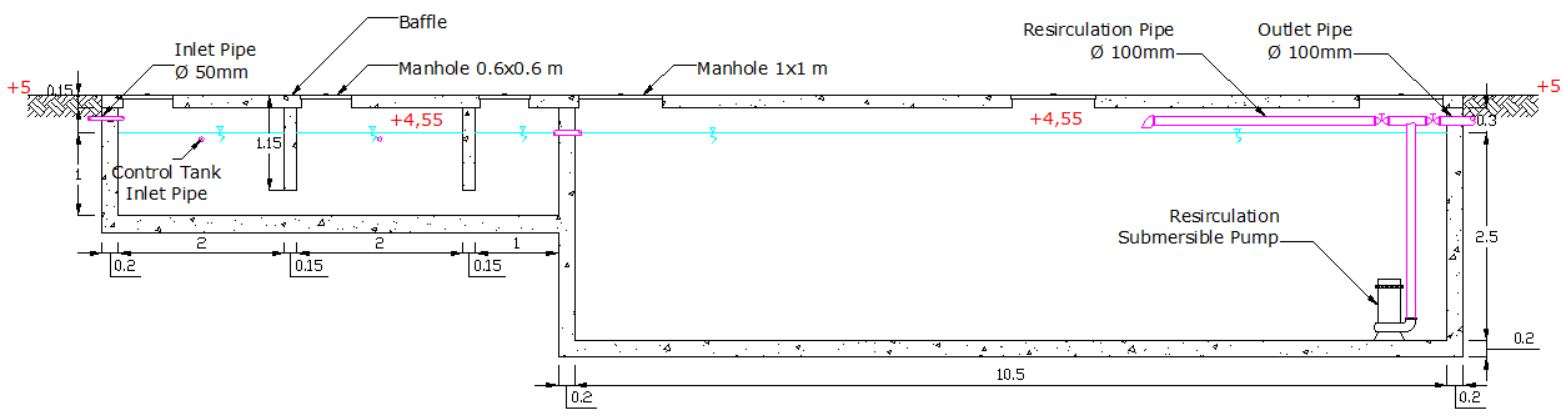

Figure 4. Section A-A' of grease trap and anaerobic filter

\subsubsection{The septic tank design}

The septic tank serves as a primary sedimentation of discrete particles that can cause a blockage in the filter media. Sludge is degraded by microorganisms present in the sludge. Design criteria for septic tank are Organic Loading Rate (OLR) $<4-5 \mathrm{~kg}$ COD $/ \mathrm{m}^{3}$.day; SSsettle/COD ratio 0.35-0.45; and Hydraulic Retention Time (HRT) 2 hours. Using the calculations based on DEWATS by Sasse (1998), the dimension of septic tank was obtained and presented in Table 4. 
Table 4. Dimension of septic tank and anaerobic filter

\begin{tabular}{lccc}
\hline \multicolumn{1}{c}{ Parameter } & Unit & Septic tank & Anaerobic filter \\
\hline Length & $\mathrm{m}$ & 4.5 & 2.5 \\
Width & $\mathrm{m}$ & 4 & 4 \\
Height & $\mathrm{m}$ & 2.5 & 2.5 \\
Number of & - & 2 & 6 \\
compartment & & & \\
\hline
\end{tabular}

\subsubsection{The anaerobic filter design}

The anaerobic filter is filled with honey comb type filter media with spesific surface area of $200 \mathrm{~m}^{2} / \mathrm{m}^{3}$ and $98 \%$ of porosity. Design criteria for anaerobic filter are Organic Loading Rate (OLR) < 4-5 kg COD/m³.day; up-flow velocity (Vup) $<2 \mathrm{~m} /$ hour; and Hydraulic Retention Time (HRT) 24-48 hours. Using the calculations based on DEWATS by Sasse (1998), the dimension of anaerobic filter can be obtained and can be seen in Table 4 and Figure 5 and 6.

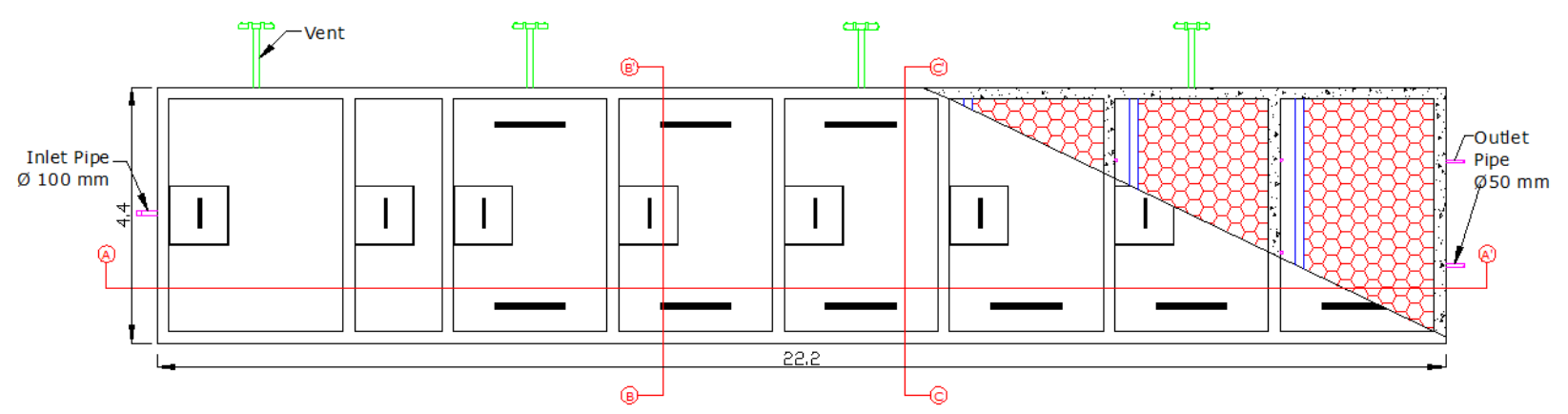

Figure 5. Top view of septic tank and anaerobic filter

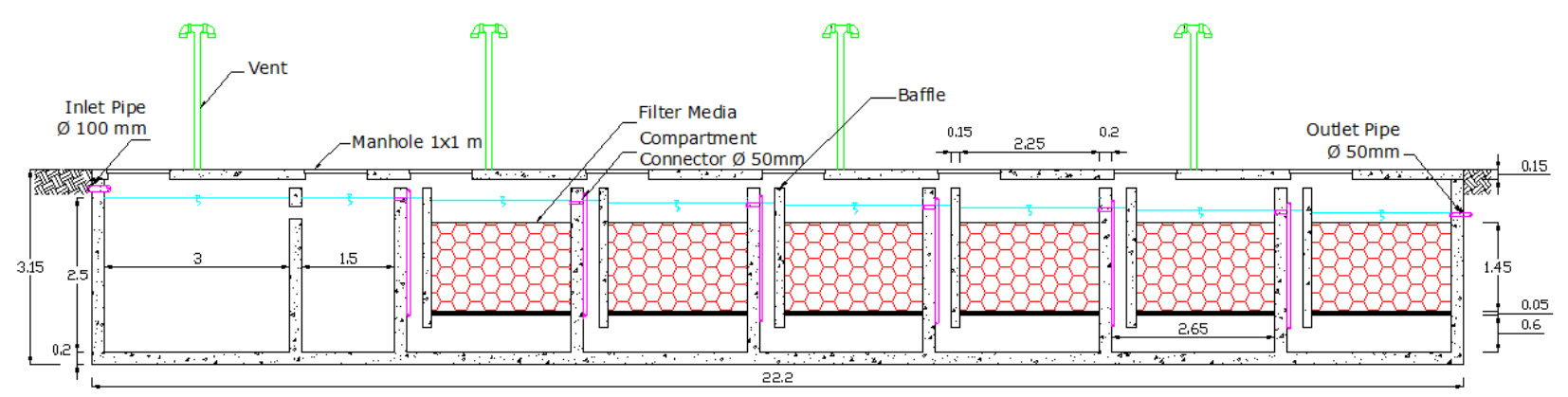

Figure 6. Section A-A' of septic tank and anaerobic filter

\subsubsection{Filter design}

Filter is used to reduce high concentration of nitrogen and phosphate. Based on SNI 06-3730-1995, activated carbon has adsorption capacity of $\mathrm{I}_{2}$ (absorption of small particles, including nitrogen) of $750 \mathrm{mg} / \mathrm{g}$, with a minimum absorption of $20 \%$. The combination of activated carbon filter media and silica sand, based on research by Chrisafitri and Karnaningroem (2012), can remove the phosphate content by $72 \%$. The dimension of filter tank can be obtained by equation (6), where $Q$ is divided by the velocity of filtration. 
The shape of filter tank designed is cylindrical, then the diameter of filter tank is determined with equation (7), using the general formula for the area of a circle.

The filter tank has a diameter of $1.5 \mathrm{~m}$. The activated carbon used as a filter media has a density of $35 \mathrm{~kg} / \mathrm{m}^{3}$. Therefore, the volume of activated carbon needed is $0.83 \mathrm{~m}^{3}$ and 0.5 $\mathrm{m}$ or $50 \mathrm{~cm}$ in height. Since the optimum height ratio between activated carbon and silica sand is 1:3 (Puspitahati, 2012), then the height needed for silica sand is $1.5 \mathrm{~m}$ or $150 \mathrm{~cm}$. The effluent wastewater from anaerobic filter will be pumped into the filter tank filled with activated carbon and silica sand (see Figure 7).

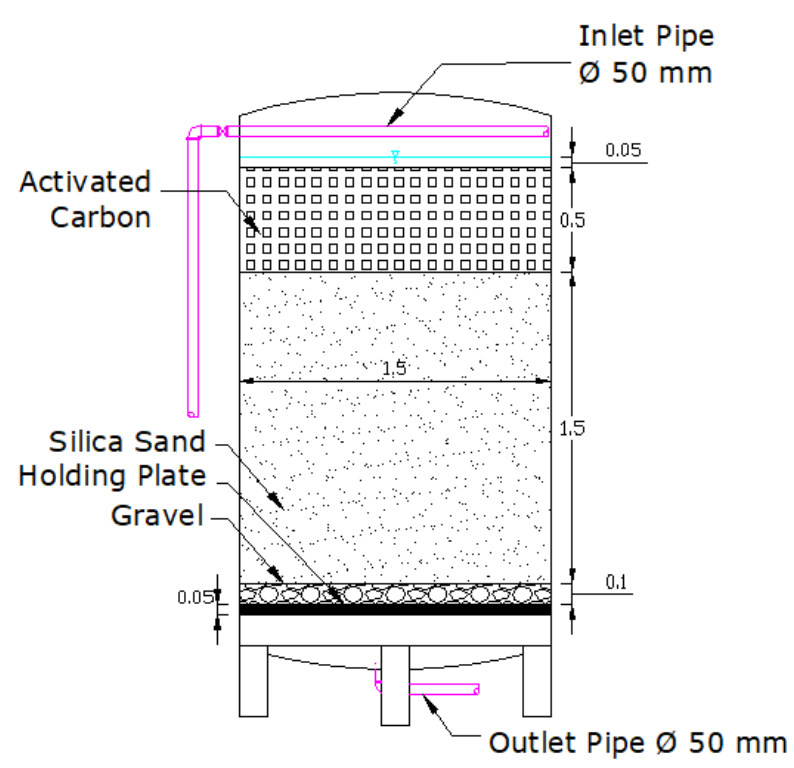

Figure 7. Section of filter with activated carbon and silica sand

\section{Conclusions}

The combined wastewater treatment system of two types of wastewater, i.e. domestic and laboratory, are chosen to save the required land and treatment units. The suitable treatment units for wastewater treatment system of The MIPA Tower are a neutralization tank $(\varnothing=0.65 \mathrm{~m}, \mathrm{H}=0.43 \mathrm{~m})$, a grease trap ( $4 \mathrm{~m} \times 2 \mathrm{~m} \times 1 \mathrm{~m})$, an equalization tank (10.5 $\mathrm{m} \times 5.5 \mathrm{~m} \times 2.5 \mathrm{~m})$, a septic tank ( $4.5 \mathrm{~m} \times 4 \mathrm{~m} \times 2.5 \mathrm{~m})$ integrated with a six-compartment anaerobic filter $(2.25 \mathrm{~m} \times 5.5 \mathrm{~m} \times 2.5 \mathrm{~m})$ and a filter with the height of activated carbon is $50 \mathrm{~cm}$, the height of silica sand is $150 \mathrm{~cm}$, the height of gravel is $10 \mathrm{~cm}$, and the diameter of the tank is $1.5 \mathrm{~m}$.

\section{Acknowledgement}

The authors would like to thank the Faculty of Mathematics and Science (FMIPA) of ITS Surabaya for the permission to carry out this study and to take the MIPA Tower office building as a case study. The authors would also like to acknowledge the Environmental Quality Management Laboratory in the Environmental Engineering Department for analyzing the characteristic of wastewater. 


\section{References}

Chrisafitri, A. dan Karnaningroem, N. 2012. "Pengolahan Air Limbah Pencucian Mobil dengan Reaktor Saringan Pasir Lambat dan Karbon Aktif". Prociding Seminar Nasional Manajemen Teknologi XVI, July 14. Surabaya: Program Studi MMT - ITS.

Facilities and Infrastructure of ITS. 2016. Water Consumption of Sepuluh Nopember Institute of Technology. Surabaya.

Hartini, E., Yuantari, MG. and Catur. 2011. Pengolahan Air Limbah Laboratorium dengan Menggunakan Koagulan Alum Sulfat dan Poly Alum Chloride di Laboratorium Kesehatan Universitas Dian Nuswantoro Semarang. Jurnal Dian, 11 (2).

Herlambang, A. 2001. "Pengaruh Pemakaian Biofilter Struktur Sarang Tawon pada Pengolah Limbah Organik Sistem Kombinasi Anaerob-Aerob (Studi Kasus: Limbah Tahu dan Tempe)". Jurnal Teknologi Lingkungan, Vol. 2, No.1.

Iskandar, S., Fransisca, I., Arianto, E. dan Ruslan, A. 2016. Sistem Pengelolaan Air Limbah Domestik - Terpusat Skala Permukiman. Jakarta: Kementerian Pekerjaan Umum dan Perumahan Rakyat Direktorat Jenderal Cipta Karya Direktorat Pengembangan Penyehatan Lingkungan Permukiman.

Mara, D. 1978. Sewage Treatment in Hot Climates (English Language Book Society Edition). London: John Wiley \& Sons, Ltd.

Martinez A., O.M., Ramirez F., J.H. dan Toledo R., M.L. 2013. “Total Organic Carbon Removal from A Chemical Lab's Wastewater Using Fenton's Reagent”. Ingeniería E Investigación, Vol. 33 No. 2, pp. 30-35.

Masduqi, A. dan Assomadi, A. F. 2012. Operasi dan Proses Pengolahan Air. Surabaya: ITS Press.

Menteri Lingkungan Hidup. 2003. Keputusan Menteri Negara Lingkungan Hidup Nomor 112 Tahun 2003 tentang Baku Mutu Air Limbah Domestik. Jakarta

Nasr, F. A., Doma, H. S., Abdel-Halim, H. S. dan El-Shafai, S. A. 2004. "Chemical Industry Wastewater Treatment". TESCE, Vol. 30, No.2.

Penny, L., Bijaksana, H.U., Yunita, R. and Itta, D. 2012. Kajian Perilaku Masyarakat Membuang Sampah di Bantaran Sungai Martapura Terhadap Lingkungan Perairan. EnviroScienteae, 8 (117-126).

Pratiwi, R. S. dan Purwanti, I. F. 2015. Perencanaan Sistem Penyaluran Air Limbah Domestik di Kelurahan Keputih Surabaya. Jurnal Teknik ITS, 4 (1).

Puspitahati, C. 2012. Studi Kinerja Biosand Filter dalam Mengolah Limbah Laundry dengan Parameter Fosfat. Undergraduate thesis. Department of Environmental Engineering, Faculty of Civil Engineering and Planning, Sepuluh Nopember Institute of Technology Sepuluh Nopember. Surabaya.

Putra, A. H. 2013. Rancang Bangun Unit Pengolahan Air Skala Rumah Tangga. Tugas Akhir. 
Jurusan Teknik Lingkungan, Fakultas Teknik Sipil dan Perencanaan Institut Teknologi Sepuluh Nopember. Surabaya.

Qasim, S. R. 1991. Wastewater Treatment Plants: Planning, Design, and Operation. New York: McGraw-Hill.

Rahardjo, P. N. 2002. Teknologi Pengolahan Limbah Cair Industri: Teknologi Pengolahan Limbah Cair dengan Proses Kimia. Jakarta: Pusat Pengkajian dan Penerapan Teknologi Lingkungan Deputi Bidang Teknologi Informasi, Energi, Material dan Lingkungan Badan Pengkajian dan Penerapan Teknologi (BPPT).

Republik Indonesia. 2001. Peraturan Pemerintah Republik Indonesia Nomor 82 tahun 2001 tentang Pengelolaan Kualitas Air dan Pengendalian Pencemaran Air. Sekretariat Negara. Jakarta.

Said, N. I. 2000. "Teknologi Pengolahan Air Limbah dengan Proses Biofilm Tercelup". Jurnal Teknologi Lingkungan, Vol. 1, No. 2.

Santoso, A. 2015. Perencanaan Pengolahan Air Limbah Domestik dengan Alternatif Media Biofilter (Studi Kasus: Kejawan Gebang Kelurahan Keputih Surabaya). Tugas Akhir. Jurusan Teknik Lingkungan ITS. Surabaya.

Santoso, S. 2014. "Limbah Cair Domestik: Permasalahan Dan Dampaknya Terhadap Lingkungan". Materi Penyuluhan Kepada Masyarakat Desa Pasinggangan, Kec. Banyumas. Purwokerto: Universitas Negeri Jenderal Soedirman.

Sasongko, L. A. 2006. Kontribusi Air Limbah Domestik Penduduk Di Sekitar Sungai Tuk Terhadap Kualitas Air Sungai Kaligarang serta Upaya Penanganannya (Studi Kasus Kelurahan Sampangan dan Bendan Ngisor Kecamatan Gajah Mungkur Kota Semarang). Thesis. Magister Program of Environmental Science, Diponegoro University Post Graduate Program. Semarang.

Sasse, L. 1998. DEWATS: Decentralised Wastewater Treatment in Developing Countries. Bremen: BORDA (Bremen Overseas Research and Development Association).

Tchobanoglous, G., Burton, F. L. and Stensel, H. D. 2014. Wastewater Engineering: Treatment and Reuse (5th Edition). New York: McGraw-Hill.

Tchobanoglous, G., Burton, F. L. dan Stensel, H. D. 2003. Wastewater Engineering: Treatment and Reuse (4th Edition). New York: McGraw-Hill.

Widayat, W. 2009. "Daur Ulang Air Limbah Domestik Kapasitas 0,9 $\mathrm{m}^{3}$ per Jam Menggunakan Kombinasi Reaktor Biofilter Anaerob Aerob dan Pengolahan Lanjutan". Jurnal Air Indonesia, Vol. 5, No. 1.

Widjajanti, E. 2009. " Penanganan Limbah Laboratorium Kimia". Kegiatan PPM Prodi Dik Kim, 13 Nopember.

Wongthanate, J., Mapracha, N., Prapagdee, B., dan Arunlertaree, C. 2014. Efficiency of Modified Grease Trap for Domestic Wastewater Treatment The Journal of Industrial Technology, 10 (2). 
Yudo, S. dan Setiyono. Januari 2008. "Perencanaan Instalasi Pengolahan Limbah Domestik di Rumah Susun Karang Anyar Jakarta". Jurnal Teknik Lingkungan, Vol. 9, No. 1, pp 31-40. 